\title{
PERFORMANCE OF APRICOT VARIETIES/GENOTYPES IN NORTH WESTERN HIMALAYAN REGION OF INDIA
}

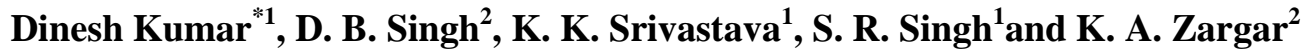 \\ ${ }^{1}$ ICAR-Central Institute for Subtropical Horticulture, Lucknow, Uttar Pradesh, India \\ ${ }^{2}$ ICAR-Central Institute of Temperate Horticulture, Srinagar, Jammu and Kashmir, India
}

\begin{abstract}
A long term experiment (2010-11 to 2014-15) was performed to evaluate the morphological and qualitative traits of apricot varieties/genotypes under north western Himalayan region of India. There were ten varieties/genotypes (CITH-Apricot-01, CITH-Apricot-02, CITH-Apricot-03, Communis, Erani, Afghani, Balcota, CITH-Apricot-09, Chinese apricot, Tokpopa Nimu ) were evaluated under RCBD with three replications. The results of five year pooled data indicated that maximum average Trunk Cross Sectional Area (TCSA) $\left(168.03 \mathrm{~cm}^{2}\right)$ was recorded in the variety Communis. Maximum fruit weight $(80.03 \mathrm{~g})$ and yield $(113.87 \mathrm{~kg} /$ tree $)$ were recorded in $\mathrm{CITH}$-Apricot-01. The productivity efficiency $(1.21 \mathrm{~kg}$ $\mathrm{cm}^{-2}$ TCSA) was noted in CITH-Apricot-02. The fruit stone ratio 21.62 was recorded in Afghani variety. The highest TSS (25.07 Brix) was estimated in CITH-Apricot-09. Acidity was noticed maximum in the variety Chinese apricot. The total sugar and non reducing sugar were manifested maximum in the apricot genotype Tokpopa Nimu and reducing sugar (8.9\%) was recorded in $\mathrm{CITH}$-Apricot-09 under the north western Himalayan region of India.
\end{abstract}

Keywords: Morphological, quantitative traits, apricot, variety/ genotype, NWHR

\section{INTRODUCTION}

Apricot (Prunus armeniaca L.) belongs to the family Rosaceae, an important stone fruits widely grown in temperate region of the world. Major apricot producing countries in the world are Turkey, Italy, Greece, Spain, USA and France (Ghorpade et al., 1995). In India, it is commercially cultivated in the state of Jammu and Kashmir, Himachal Pradesh and Uttarakhand (Parmar and Kaushal 1982; Parmar and Sharma 1992; Sharma2000). The total area under apricot cultivation is 4886 ha with an annual production of 16739 tonnes and productivity only $3.43 \mathrm{t} \mathrm{ha}^{-1}$ (FAO 2011). The fruits of apricot are highly nutritious and rich in vitamin and minerals. Primarily,

* Corresponding author email: dkches@ rediffmail.com

Received: 20.09.2016 
it is consumed as fresh and in smaller quantity, it is processed to juice, puree, jam, and dried fruit (Radi et al., 1997 and Schmitzer et al., 2011). The $\beta$ - carotene and lycopene activity of apricots may prevent the heart disease in human. It is a good source of fibre, which has a health benefit such as prevents digestive conditions called as diverculosis. These fruits are antipyretic, antiseptic, emetic and ophthalmic (Pramar and Kaushal, 1982). The decoction of apricot bark is used to smooth inflamed and irritated skin conditions (Chevallier, 1996). Moreover, apricot kernel is used in production of oil, benzydehyde, cosmetic activity, carbon and aroma perfume (Yildiz, 1994). Due to low sugar and moderate high acidity, the apricot varieties grown in mid hills and valley areas are not suitable for drying (Sharma et al., 2004).

Fresh apricots fruit is a good source of fibres, minerals especially potassium and vitamins such as vitamin $\mathrm{A}$, vitamin $\mathrm{C}$, thiamin, riboflavin, niacin and pantothenic acid (Lichou et al., 2003). The chilling requirement of this crop ranges from 300 to 900 chill unit depending upon the variety and genotypes. The molecular studies have been integrated into the conventional germplasm characterization (Ali et al., 2008; Akpinar et al., 2010; Mratinic et al., 2011; Pinar et al., 2013 and Kumar et al., 2016).The main reason for the low productivity of apricot is to identify the variety and technology best suited to particular agroecological condition. In order to improve the productivity, an experiment was under taken to evaluate the varieties/genotypes for specific traits under north western Himalayan region of India.

\section{MATERIALS AND METHODS}

An experiment was conducted at the ICAR-Central Institute of Temperate Horticulture, Srinagar during 2010-11 to 2014-15. The Research farm at Srinagar is situated at latitude of $34^{\circ} 05^{\prime} \mathrm{N}$, longitude of $74^{\circ} 50^{\prime} \mathrm{E}$ and altitude of $1640 \mathrm{~m}$ above msl. The soils of this experimental field are sandy clay loam (45-55\% sand, 10-20\% Silt and 20-25\% clay; 6.5-7.5 soil $\mathrm{pH}, 0.50 \%$ organic carbon, $462.1 \mathrm{~kg} \mathrm{~N}^{-1}, 9.59$ $\mathrm{kg} \mathrm{P} \mathrm{ha}{ }^{-1}$ and $278.85 \mathrm{~kg} \mathrm{~K} \mathrm{ha}^{-1}$ ) with poor drainage. The experiment was laid out in a randomized complete block design (RCBD) with three replications. The apricot varieties budded/grafted on seedling rootstocks and planted in 2003 at a spacing of 5 $\mathrm{m} \times 5 \mathrm{~m}$ were used as study material. Ten varieties/genotypes of apricot (CITHApricot-01, CITH-Apricot-02, CITH-Apricot-03, Communis, Erani, Afghani, Balcota, CITH-Apricot-09, Chinese apricot, Tokpopa Nimu) were evaluated for growth, yield and quality. The plants were trained on modified central leader system and applied uniform recommended cultural practices to all the trees under study. The experimental farm falls under temperate region having cold conditions from November to February and total average annual rainfall received during the cropping season was $710 \mathrm{~mm}$. Observations on growth, yield and quality were recorded. The trunk cross-sectional area was calculated by using formula TCA $=$ Girth $^{2} / 4 \pi$ (Westwood et al., 1963). Fruit was harvested at maturity and yield per tree was estimated in kilogram. Fruit, stone and kernel size were determined by observing the length and diameter and measured by Vernier callipers. Ten fruits were randomly 
selected from each tree and pooled as per replication in all treatments for quality analysis. The total soluble solids (TSS) of fruits were estimated by the hand refractometer $\left(0\right.$ to $\left.32^{0} \mathrm{~B}\right)$ and the results were expressed as degree Brix $\left({ }^{0} \mathrm{~B}\right)$. To estimate TSS, fruit pulp was crushed in a pestle and mortar and then squeezed through a muslin cloth for extraction of juice. The titratable acidity expressed in terms of percentage of citric acid was recorded by titrating $2 \mathrm{ml}$ of juice against N/10 sodium hydroxide using phenolphthalein as an indicator. The total and reducing sugars of fruit were estimated by Lane and Eynon following volumetric method (AOAC, 1980) by titrating the sample against Fehlings solutions. The data of five years and pooled data for quality parameters were analyzed statistically as per Steel and Torrie (1984) for the interpretation of results and drawing conclusions.

\section{RESULTS AND DISCUSSION}

\section{Trunk Cross Sectional Area (TCSA)}

Results on Trunk Cross Sectional Area (TCSA) of the tree is presented in table 1 indicted that the TCSA increased over the years from 2010-11 to 2014-15 in all the varieties/genotypes in apricot. Significantly maximum TCSA $\left(140.34 \mathrm{~cm}^{2}\right)$ was recorded in Afghani variety closely followed by the genotype CITH-Apricot-09 $\left(135.85 \mathrm{~cm}^{2}\right)$ and variety Communis $\left(135.48 \mathrm{~cm}^{2}\right)$, respectively in 2010-11. In 201112, maximum TCSA $\left(155.64 \mathrm{~cm}^{2}\right)$ was recorded in variety Afghani followed by Communis $\left(154.96 \mathrm{~cm}^{2}\right)$ and CITH-Apricot $09\left(154.82 \mathrm{~cm}^{2}\right)$, respectively. In 201213 and 2013-14, maximum TCSA $\left(169.36 \mathrm{~cm}^{2}\right.$ and $\left.182.45 \mathrm{~cm}^{2}\right)$ was recorded in Communis variety followed by CITH-Apricot- $09\left(168.25 \mathrm{~cm}^{2}\right.$ and $\left.182.36 \mathrm{~cm}^{2}\right)$ and Afghani $\left(162.58 \mathrm{~cm}^{2}\right.$ and $\left.175.26 \mathrm{~cm}^{2}\right)$, respectively. In 2014-15, the highest TCSA $\left(198.70 \mathrm{~cm}^{2}\right)$ was noticed in CITH-Apricot-09 followed by Communis $\left(197.88 \mathrm{~cm}^{2}\right)$ and Afghani $\left(191.24 \mathrm{~cm}^{2}\right)$, respectively. An overall mean for five years data indicated that maximum TCSA $\left(168.03 \mathrm{~cm}^{2}\right)$ was noted in Communis followed by CITHApricot $-09\left(168.0 \mathrm{~cm}^{2}\right)$ and Afghani $\left(165.01 \mathrm{~cm}^{2}\right)$ respectively in apricot. Maximum TCSA was observed in Communis variety of apricot might be due to heredity character of the variety, which increases the TCSA by increasing the uptake of nutrients from root to aerial part of the tree. Similar finding on apricot was reported by Kumar et al. (2013). 
Table 1. Trunk Cross Sectional Area of tree as influenced by apricot varieties/genotypes

\begin{tabular}{|c|c|c|c|c|c|c|c|}
\hline \multirow[t]{2}{*}{ S.No. } & \multirow[t]{2}{*}{ Varieties/genotypes } & \multicolumn{6}{|c|}{$\operatorname{TCSA}\left(\mathrm{cm}^{2}\right)$} \\
\hline & & $\begin{array}{l}2010- \\
11\end{array}$ & $\begin{array}{l}2011- \\
12\end{array}$ & $\begin{array}{l}2012- \\
13\end{array}$ & $\begin{array}{l}2013- \\
14\end{array}$ & $\begin{array}{l}2014- \\
15\end{array}$ & Average \\
\hline 1 & CITH-Apricot-01 & 98.26 & 114.65 & 129.21 & 143.45 & 158.63 & 128.84 \\
\hline 2 & CITH-Apricot-02 & 61.69 & 68.83 & 75.45 & 92.23 & 104.86 & 80.61 \\
\hline 3 & CITH-Apricot-03 & 81.23 & 92.38 & 108.24 & 122.87 & 137.35 & 108.41 \\
\hline 4 & Communis & 135.48 & 154.96 & 169.36 & 182.45 & 197.88 & 168.03 \\
\hline 5 & Erani & 82.68 & 97.54 & 111.29 & 124.69 & 139.38 & 111.12 \\
\hline 6 & Afghani & 140.34 & 155.64 & 162.58 & 175.26 & 191.24 & 165.01 \\
\hline 7 & Balcota & 57.52 & 61.96 & 69.45 & 91.95 & 101.22 & 76.42 \\
\hline 8 & CITH-Apricot-09 & 135.85 & 154.82 & 168.25 & 182.36 & 198.70 & 167.99 \\
\hline 9 & Chinese Apricot & 55.26 & 61.21 & 65.24 & 70.26 & 81.70 & 66.73 \\
\hline \multirow[t]{2}{*}{10} & Tokpopa Nimu & 135.34 & 148.63 & 162.47 & 175.56 & 190.81 & 162.56 \\
\hline & $\mathrm{CD}$ at $5 \%$ & 35.12 & 32.75 & 34.16 & 36.26 & 37.12 & - \\
\hline
\end{tabular}

\section{Flowering and fruit set}

Flowering and fruit set in apricot was influenced by varieties/genotypes (Table 2). The time of bud burst ranged from 19.03.2014 to 22.03.2014 (4 days), first flowering from 25.03.2014 to 29.03.2014 (4 days), 75\% flowering from 29.03.2014 to 03.04.2014 (6 days), full bloom from 03.04.2014 to 07.04.2014 (5 days) and fruit set from 10.04.2014 to 13.04.2014 (4 days) in apricot varieties/genotypes. Minimum 21 days taken from bud burst to fruit set in Erani variety and maximum 25 days taken in CITH-Apricot-02. There were less variations in terms of flowering and fruit set among the apricot varieties/genotypes. The variations in flowering/fruit set might be due to varietal characters.

Table 2. Bud burst, flowering and fruit set as influenced by apricot variety/genotype

\begin{tabular}{l|l|c|c|c|c|c|c}
\hline S. No. & Variety/genotype & $\begin{array}{c}\text { Date of bud } \\
\text { burst }\end{array}$ & $\begin{array}{c}\mathbf{1}^{\text {st }} \text { flower } \\
\text { open }\end{array}$ & $\begin{array}{c}\mathbf{7 5 \%} \\
\text { flowering }\end{array}$ & Full bloom & $\begin{array}{c}\text { Date of fruit } \\
\text { set }\end{array}$ & $\begin{array}{c}\text { Total days (bud } \\
\text { burst to fruit } \\
\text { set) }\end{array}$ \\
\hline
\end{tabular}




\begin{tabular}{l|l|c|c|c|c|c|c}
\hline S. No. & Variety/genotype & $\begin{array}{c}\text { Date of bud } \\
\text { burst }\end{array}$ & $\begin{array}{c}\mathbf{1}^{\text {st }} \text { flower } \\
\text { open }\end{array}$ & $\begin{array}{c}\mathbf{7 5 \%} \\
\text { flowering }\end{array}$ & Full bloom & $\begin{array}{c}\text { Date of fruit } \\
\text { set }\end{array}$ & $\begin{array}{c}\text { Total days (bud } \\
\text { burst to fruit } \\
\text { set) }\end{array}$ \\
\hline & 6. Afghani & $21-03-2014$ & $27-03-2014$ & $27-03-2017$ & $03-04-2014$ & $10-04-2014$ & 21 \\
7. Balcota & $20-03-2014$ & $28-03-2014$ & $31-03-2014$ & $04-04-2014$ & $11-04-2014$ & 22 \\
8. CITH-AP-09 & $22-03-2014$ & $27-03-2014$ & $03-04-2014$ & $07-04-2014$ & $13-04-2014$ & 23 \\
9. Chinese Apricot & $21-03-2014$ & $29-03-2014$ & $03-04-2014$ & $07-04-2014$ & $13-04-2014$ & 24 \\
10 Tokpopa Nimu & $22-03-2014$ & $27-03-2014$ & $31-03-2014$ & $05-04-2014$ & $12-04-2014$ & 22 \\
\hline
\end{tabular}

\section{Fruit Yield}

Fruit yield is one of the most important parameters that indicates the potentiality of variety/genotype (Table 3). The fruit yield per tree as influenced by varieties/genotypes in apricot over the years. There was increasing and decreasing trend of fruit yield per tree in different year starting from 2011-12 to 2014-15 in all the varieties/ genotypes. Maximum fruit yield $\left(87.06 \mathrm{~kg} \mathrm{tree}^{-1}\right)$ was registered in CITH-Apricot-01(87.06 kg tree $\left.{ }^{-1}\right)$ followed by Erani $\left(63.12 \mathrm{~kg} \mathrm{tree}^{-1}\right)$ and CITHApricot-02 (62.07 kg tree $\left.{ }^{-1}\right)$ in 2010-11. In 2011-12, the highest fruit yield (161.34 kg tree $^{-1}$ ) was recorded in CITH-Apricot -01 and significantly superior over other varieties/genotypes under evaluation. Similar increasing trends were also recorded during 2012-13 in CITH-Apricot-01 (170.6 kg tree $\left.{ }^{-1}\right)$ followed by Erani $(108.15 \mathrm{~kg}$ tree $^{-1}$ ) and CITH-Apricot-02 (95.22 $\left.\mathrm{kg} \mathrm{tree}^{-1}\right)$, respectively. The fruit yield per tree decreased in the year 2013-14 by $39.79 \%$ in CITH-Apricot-01, 39.21\% in CITHApricot-02 and $54.68 \%$ in CITH-Apricot-03 compared to those of the germplasm in 2012-13. In 2014-15, the fruit yield per tree was drastically reduced and it was noticed maximum in CITH-Apricot-03 $\left(59.12 \mathrm{~kg}\right.$ tree $\left.^{-1}\right)$ followed by CITH-Apricot$02\left(57.56 \mathrm{~kg} \mathrm{tree}^{-1}\right)$ and CITH-Apricot-01 (47.65 kg tree $\left.{ }^{-1}\right)$, respectively. The overall five year mean of fruit yield indicated that the highest fruit yield $\left(113.87 \mathrm{~kg}\right.$ tree $\left.{ }^{-1}\right)$ was recorded in CITH-Apricot-01 followed by CITH-Apricot-02 $\left(92.96 \mathrm{~kg}\right.$ tree $\left.{ }^{-1}\right)$ and CITH-Apricot-03 $\left(73.73 \mathrm{~kg}\right.$ tree $\left.^{-1}\right)$ in apricot variety/genotype. The better performance of CITH-Apricot-01, CITH-Apricot-02 and CITH-Apricot-03 might be due to inherent vigour and bearing habit of the apricot variety. Similar findings were reported by Kumar et al. (2013), in apricot under Kashmir conditions. 
Table 3. Fruit yield as influenced by apricot varieties/genotypes

\begin{tabular}{l|l|l|l|l|l|l|l}
\hline S.No. & Varieties/genotypes & \multicolumn{5}{|c}{ Fruit yield $\left(\mathrm{kg} \mathrm{tree}^{-1}\right)$} \\
\cline { 3 - 8 } & & $2010-11$ & $2011-12$ & $2012-13$ & $2013-14$ & $2014-15$ & Average \\
\hline 1 & CITH-Apricot-01 & 87.06 & 161.34 & 170.6 & 102.72 & 47.65 & 113.87 \\
2 & CITH-Apricot-02 & 62.07 & 155.35 & 95.22 & 94.62 & 57.56 & 92.96 \\
3 & CITH-Apricot-03 & 53.45 & 134.09 & 60.77 & 61.23 & 59.12 & 73.73 \\
4 & Communis & 47.24 & 81.30 & 49.48 & 38.99 & 37.77 & 50.96 \\
5 & Erani & 63.12 & 76.70 & 108.15 & 66.64 & 38.65 & 70.65 \\
6 & Afghani & 47.87 & 62.86 & 75.78 & 48.40 & 39.38 & 54.78 \\
7 & Balcota & 38.56 & 52.97 & 48.63 & 25.24 & 12.86 & 35.65 \\
8 & CITH-Apricot-09 & 25.36 & 36.73 & 48.12 & 16.85 & 12.76 & 27.96 \\
9 & Chinese Apricot & 23.15 & 30.41 & 21.22 & 15.36 & 7.99 & 19.63 \\
10 & Tokpopa Nimu & 20.24 & 21.65 & 14.64 & 56.47 & 6.24 & 23.85 \\
& CD at 5\% & 20.24 & 35.12 & 38.27 & 21.15 & 18.15 & - \\
\hline
\end{tabular}

\section{Productivity efficiency}

Data on productivity efficiency was influenced by variety/genotype in apricot (Table 4). There were increasing/decreasing trends over the years from 2010-11 to 2014-15 in all the treatments. Maximum productivity efficiency $\left(0.99 \mathrm{~kg} \mathrm{~cm}^{-2}\right.$ TCSA) was recorded in CITH-Apricot-02 followed by CITH-Apricot-01 $\left(0.88 \mathrm{~kg} \mathrm{~cm}^{-2}\right.$ TCSA) and Erani (0.76 kg cm${ }^{-2}$ TCSA) in 2010-11. In 2011-12, the highest productivity efficiency $\left(2.25 \mathrm{~kg} \mathrm{~cm}^{-2}\right.$ TCSA) was recorded in CITH-Apricot-02 followed by CITH-Apricot-03 (1.45 kg cm${ }^{-2}$ TCSA) and CITH-Apricot- $01(1.40 \mathrm{~kg}$ $\mathrm{cm}^{-2}$ TCSA), respectively. Marginal reduction in productivity efficiency was obtained $1.32 \mathrm{~kg} \mathrm{~cm}^{-2}$ TCSA from CITH-Apricot-01 and $1.26 \mathrm{~kg} \mathrm{~cm}^{-2}$ TCSA from CITHApricot-02 in the year 2012-13. However, drastic reduction in productivity efficiency was happened during 2013-14 and 2014-15 in all the variety/genotype under evaluation. The productivity efficiency values $\left(1.02 \mathrm{~kg} \mathrm{~cm}^{-2}\right.$ TCSA and $0.55 \mathrm{~kg} \mathrm{~cm}^{-2}$ TCSA) were registered in CITH-Apricot- 02 followed by CITH-Apricot- $01(0.72 \mathrm{~kg}$ $\mathrm{cm}^{-2}$ TCSA and $0.30 \mathrm{~kg} \mathrm{~cm}^{-2}$ TCSA $)$ and minimum $\left(0.09 \mathrm{~kg} \mathrm{~cm}^{-2}\right.$ TCSA and $0.06 \mathrm{~kg}$ $\mathrm{cm}^{-2}$ TCSA) in CITH-Apricot-09. The overall mean value indicated that the highest productivity efficiency $\left(1.21 \mathrm{~kg} \mathrm{~cm}^{-2}\right.$ TCSA) was recorded in CITH-Apricot-02 followed by CITH-Apricot-01 $\left(0.92 \mathrm{~kg} \mathrm{~cm}^{-2}\right.$ TCSA) and CITH-Apricot-03 $(0.72 \mathrm{~kg}$ $\mathrm{cm}^{-2}$ TCSA) in apricot variety/genotype. Maximum productivity efficiency in CITHApricot-01, CITH-Apricot-02 and CITH-Apricot-03 might be due to the positive relationship between TCSA and yield. Similar positive relationship was also reported by Kumar et al., 2008. 
Table 4. Productivity efficiency as influenced by apricot varieties/genotypes

\begin{tabular}{|c|c|c|c|c|c|c|c|}
\hline \multirow[t]{2}{*}{ S.No. } & \multirow[t]{2}{*}{ Varieties/genotypes } & \multicolumn{5}{|c|}{ Productivity efficiency $\left(\mathrm{kg} \mathrm{cm}^{-2} \mathrm{TCSA}\right)$} & \multirow[t]{2}{*}{ Average } \\
\hline & & $2010-11$ & 2011-12 & $2012-13$ & 2013-14 & 2014-15 & \\
\hline 1 & CITH-Apricot-01 & 0.88 & 1.40 & 1.32 & 0.72 & 0.30 & 0.92 \\
\hline 2 & CITH-Apricot-02 & 0.99 & 2.25 & 1.26 & 1.02 & 0.55 & 1.21 \\
\hline 3 & CITH-Apricot-03 & 0.65 & 1.45 & 0.56 & 0.50 & 0.43 & 0.72 \\
\hline 4 & Communis & 0.35 & 0.52 & 0.29 & 0.21 & 0.19 & 0.31 \\
\hline 5 & Erani & 0.76 & 0.78 & 0.97 & 0.53 & 0.28 & 0.66 \\
\hline 6 & Afghani & 0.34 & 0.40 & 0.47 & 0.28 & 0.21 & 0.34 \\
\hline 7 & Balcota & 0.67 & 0.85 & 0.70 & 0.27 & 0.13 & 0.52 \\
\hline 8 & CITH-Apricot-09 & 0.19 & 0.24 & 0.29 & 0.09 & 0.06 & 0.17 \\
\hline 9 & Chinese Apricot & 0.42 & 0.49 & 0.32 & 0.22 & 0.09 & 0.31 \\
\hline \multirow[t]{2}{*}{10} & Tokpopa Nimu & 0.15 & 0.15 & 0.09 & 0.32 & 0.03 & 0.15 \\
\hline & $\mathrm{CD}$ at $5 \%$ & 0.18 & 0.26 & 0.28 & 0.19 & 0.16 & - \\
\hline
\end{tabular}

\section{Fruit quality}

Fruit quality parameters like fruit weight, fruit/stone weight ratio, TSS, acidity and total, reducing and non reducing sugar of apricot fruit were influenced by variety/genotype (Table 5). The fruit weight of apricot varied from 23.14 to $80.03 \mathrm{~g}$, the significantly highest fruit weight $(80.03 \mathrm{~g})$ was noted in CITH-Apricot-01 followed by CITH-Apricot-02 (69.0 g) and Communis (51.44 g), respectively. The fruit /stone wt. ratio, an important character for quality of fruits, the highest ratio (21.62) was recorded in Afghani followed by Communis (20.41) and Erani (12.87), respectively. Total soluble solids of apricot fruits varied from 14.67 to $25.07^{0} \mathrm{Brix}$, the highest TSS $\left(25.30^{\circ}\right.$ Brix $)$ was estimated in Tokpopa Nimu followed by CITHApricot-09 $\left(25.07^{0}\right.$ Brix $)$ and Afghani $\left(22.4^{0}\right.$ Brix $)$, respectively. Acidity was recorded the highest $(0.65 \%)$ in Chinese Apricot and superior to other varieties/genotypes. Total sugar, reducing and non reducing sugar varied from 8.4 to $14.6 \%, 5.3-8.9 \%$ and 1.4-6.4 \%, maximum total and non reducing sugar (14.6\% and $6.4 \%)$ was estimated in Tokpopa Nimu variety and reducing sugar $(9.7 \%)$ was registered maximum in Balcota variety of apricot. The better fruit quality of respective variety/genotype might be due to inherent character of the particular variety/genotype. Similar findings were reported by Kumar et al., 2015. 
Table 5. Fruit quality as influenced by apricot varieties/genotypes

\begin{tabular}{l|l|c|c|c|c|c|c|c}
\hline $\begin{array}{c}\text { S. } \\
\text { No. }\end{array}$ & \multicolumn{1}{c|}{$\begin{array}{c}\text { Variety/ } \\
\text { genotype }\end{array}$} & $\begin{array}{c}\text { Fruit wt } \\
(\mathrm{g})\end{array}$ & $\begin{array}{c}\text { Fruit } \\
\text { /stone wt } \\
\text { ratio }\end{array}$ & $\begin{array}{c}\text { TSS } \\
\left({ }^{0} \mathrm{Brix}\right)\end{array}$ & $\begin{array}{c}\text { Acidity } \\
(\%)\end{array}$ & $\begin{array}{c}\text { Total } \\
\text { sugar } \\
(\%)\end{array}$ & $\begin{array}{c}\text { Reducing } \\
(\%)\end{array}$ & $\begin{array}{c}\text { Non } \\
\text { reducing } \\
(\%)\end{array}$ \\
\hline 1 & CITH-Apricot-01 & 80.03 & 7.31 & 18.53 & 0.22 & 10.5 & 6.4 & 4.1 \\
2 & CITH-Apricot-02 & 69.00 & 8.42 & 17.00 & 0.34 & 9.5 & 5.3 & 4.2 \\
3 & CITH-Apricot-03 & 35.44 & 9.68 & 19.67 & 0.36 & 8.4 & 6.5 & 1.9 \\
4 & Communis & 51.44 & 20.41 & 18.80 & 0.23 & 8.5 & 7.1 & 1.4 \\
5 & Erani & 48.94 & 12.87 & 19.60 & 0.33 & 13.3 & 8.4 & 4.9 \\
6 & Afghani & 23.14 & 21.62 & 22.40 & 0.31 & 8.6 & 7.2 & 1.4 \\
7 & Balcota & 34.80 & 8.65 & 20.60 & 0.55 & 11.5 & 9.7 & 1.8 \\
8 & CITH-Apricot-09 & 41.13 & 8.04 & 25.07 & 0.54 & 13.4 & 8.9 & 4.5 \\
9 & Chinese Apricot & 41.21 & 11.01 & 14.67 & 0.65 & 7.8 & 5.3 & 2.9 \\
10 & Tokpopa Nimu & 39.90 & 6.86 & 25.30 & 0.52 & 14.6 & 8.2 & 6.4 \\
& CD at 5\% & 15.12 & 7.18 & 3.25 & 0.18 & 2.26 & 1.5 & 1.2 \\
\hline
\end{tabular}

CONCLUSIONS

The experimental results revealed that the newly identified genotypes CITH-Apricot01, CITH-Apricot-02 and CITH-Apricot-03 performed better in respect to fruit yield $\left(113.87 \mathrm{~kg} \mathrm{tree}^{-1}, 92.96 \mathrm{~kg}\right.$ tree $\mathrm{e}^{-1}$ and $73.73 \mathrm{~kg}$ tree $^{-1}$, respectively) and quality under north west Himalayan region of India.

\section{REFERENCES}

Akpinar, A. E., Kocal, H., Ergul, A., Kazan, K., Selli, M. E., Bakir, M., Aslantas, S., Kaymak, S. and Saribas, R. 2010. SSR-based molecular analysis of economically important Turkish apricot cultivars. Genetics and Molecular Research, 9: 324-332

Ali Khan, M., Maghuly, F., Borroto-Fernandez, E. G., Pedryc, A., Katinger, H. and Laimer, M. 2008. Genetic diversity and population structure of apricot (Prunus armeniaca L.) from Northern Pakistan using Simple Sequence Repeats. Silvae Genetica, 57(3), 157164

AOAC. 1980. Official Methods of Analysis, pp.1010. Association of Official Analytical Chemists, Benjamin Franklin Station Washington, D C, USA

Chevallier, A. 1996. The encyclopedia of medicinal plants. Dorling Kindersly, London

FAO. 2011. Food and Agriculture Organization of the United Nations. http:// faostat 3. fao.org. 
Ghorpade, V. M., Hanna, M. A., Kadam, S. S. 1995. Apricots. In: Salunkhe D. K, Kadam, S. S (eds) Handbook of fruit science and technology. Marcel Dekker, New York, pp. 335361

Kumar, D., Lal, S. and Ahmed, N. 2016. Genetic diversity among plum genotypes in North West Himalayan Region of India. Indian Journal of Agricultural Sciences, 86 (5): 666 672

Kumar, D., Lal, S. and Ahmed, N. 2015. Morphological and pomological diversity among apricot (Prunus armeniaca) genotypes grown in India. Indian Journal of Agricultural Sciences, 85 (10): 1349-1355

Kumar, D., Pandey, V., Anjaneyulu, K. and Vishal Nath. 2008. Relationship of trunk cross sectional area with fruit yield, quality and leaf nutrient status in Allahabad Safeda guava (Psidium guajava L.). Indian Journal of Agricultural Sciences, 78(4): 337-339

Kumar, D., Ahmed, N., Srivastava, K. K. and Dar, T. A. 2014. Effect of cross sectional area of rootstock on growth, yield, quality and leaf nutrient status in apricot (Prunus armeniaca) cv CITH-Apricot-2. Indian Journal of Agricultural Sciences, 84(2):236240.

Kumar, D., Ahmed, N., Verma, M. K. and DAR, T. A. 2013. Growth, yield and leaf nutrient status as influenced by planting densities and varieties of apricot. Indian Journal of Horticulture, 70(2):126-130

Lichou, J., Jay, M., Vaysse., P. and Lespinasse. N. 2003. Reconnaitre les variétés d'abricots. Ctifl, Paris, France, pp 17-29

Mratinic, E., Popovski, B., Milosevis, T. and Popovski, M. 2011. Analysis of morphological and pomological characteristics of apricot germplasm in FYR Macedonia. Journal of Agricultural Science and Technology, 13:1121-1134

Parmar, C. and Kaushal, M. K. 1982. Prunus armeniaca L. In: Wild fruits. Kalyani Publishers, New Delhi, pp. 66-69

Pinar, H., Unlu, M., Ercisli, S., Uzum, A., Bircan, M., Yilmaz, K. U. and Agar, G. 2013. Determination of genetic diversity among wild grown apricots from Sakit valley in Turkey using SRAP markers. Journal of Applied Botany and Food Quality, 86:55-58. DOI:10.5073/JABFQ.2013.086.008

Radi, M., Mahrouz, M., Jaouad, A. 1997. Phenolic content, browning susceptibility and carotenoid content of several apricot cultivars at maturity. Hort Science, 32:1087-1091.

Schmitzer, V., Slatnar, A., Mikulic-Petkovsek, M., Veberic, R., Krskab, B. and Stampar, F. 2011. Comparative study of primary and secondary metabolites in apricot (Prunus armeniaca L.) cultivars. Journal of Science Food and Agriculture, 91(5):860-867

Sharma, J. K. 2000. Morphological studies on apricot \& its wild relatives. Journal of HillResearch, 13(1):5-10

Sharma, K. D., Kumar, R. and Kaushal, B. B. 2004. Mass transfer characteristics, yield and quality of five varieties of osmotically dehydrated apricot. Journal of Food Science and Technology, 41: 264-275 
Sharma, R., Gupta, A., Abrol, G. S. and Joshi, V. K. 2014. Value added of wild apricot fruits grown in North-West Himalayan regions-a review. Journal of Food Science and Technology, 51 (11):2917-2924

Singh, D. B., Kumar, D. and Ahmed, N. 2016. Evaluation of apricot genotypes for table use, drying and their storage life. Indian Journal of Agricultural Sciences, 86 (4): 527-532

Steel, R. G. T. and Torrie, J. H. 1986. Principles and Procedure of Statistics. McGraw Hill International Book Co., Singapore, pp. 348-354

Westwood, M. N., Reimer, F. C. and Quackenbush, V. L. 1963. Long term yield as related to ultimate tree size of three pears varieties grown on rootstocks of five Pyrus species. Proceeding of American Society of Horticulture Science, 82: 103-108

Yildiz, F. 1994. New Technology in apricot processing. Journal of Standard Apricot Special Issue: 67-69 